\title{
O ZNACZENIU TRADYCYJNEJ KONSTRUKCJI PRAWNEJ SAMORZĄDU TERYTORIALNEGO W WARUNKACH WSPÓŁCZESNOŚCI
}

\section{UWAGI WSTĘPNE}

Samorząd terytorialny jest przedmiotem zainteresowania różnych dyscyplin naukowych ${ }^{1}$, w tym nauk prawnych, przy czym o ile przedstawiciele innych nauk poddają oglądowi naukowemu każdy przejaw samorządności w skali lokalnej, o tyle prawnicy przez długi czas badali fenomen samorządu terytorialnego jako sformalizowanej instytucji prawnej - korporacji (zrzeszenia) lokalnego społeczeństwa samodzielnie wykonującego funkcje administracji publicznej. Inaczej rzecz ujmując, zajmowali się samorządem terytorialnym jako zdecentralizowana administracją publiczną․

Reformy decentralizacyjne administracji publicznej rozumianej przedmiotowo wespół z przejmowaniem przez samorząd innych funkcji, wykraczających poza wąsko pojmowaną administracja, spowodowały, że w obcej literaturze przedmiotu pojawił się trend do coraz szerszego rozumienia samorządu terytorialnego ${ }^{3}$. Trend ten pojawił się także w literaturze polskiej po przemianach ustrojowych lat 1989-19904. Ten stan rzeczy spowodował istotną zmianę akcentów w zainteresowaniach badawczych przedstawicieli nauk prawnych. To już nie funkcje wykonawcze państwa realizowane przez samorząd terytorialny, ale te nowe funkcje społeczne samorządu staja się osią rozważań. Samorząd terytorialny urasta $\mathrm{w}$ tych rozważaniach do rangi podmiotu wychodzącego poza system administracji publicznej (władzy wykonawczej) państwa ${ }^{5}$.

1 Koncepcje samorządu terytorialnego formułowane ze stanowiska innych nauk (ekonomicznych, teorii organizacji i zarządzania oraz psychologii politycznej) analizuje Błaś (2002), wykazując rozbieżność twierdzeń i oczekiwań wobec samorządu.

2 Szeroko na ten temat Niewiadomski (2011): $115 \mathrm{n}$.

3 Zob. np. Box (2007); Guy (1999) oraz Fox, Miller (1995).

4 Zob. np. Piekara (1990): 8.

${ }_{5}^{5} \mathrm{~W}$ ślad za tym następuje zmiana akcentów badawczych, choć w niektórych państwach (Niemcy) - po okresie fascynacji społecznymi funkcjami samorządu - uwaga badawczy skupia się na mechanizmach współdziałania, czy wręcz integracji, administracji rządowej i samorządowej. To, co jeszcze do niedawna było cechą rozpoznawczą samorządu terytorialnego - jego prawne wyodrębnienie, zdaje się tracić na znaczeniu, a w to miejsce pojawia się teza o potrzebie budowania „państwowo-komunalnych związków panowania”, u podstaw której leży sprawność w zaspokajaniu zbiorowych potrzeb lokalnych społeczności. Na marginesie warto zauważyć, że i w Polsce efektywność i sprawność w działaniu administracji publicznej nabiera znaczenia, co znajduje wy- 
Samorzą zaczyna być rozumiany jako instytucja wykraczająca poza dotychczasowe jurydyczne schematy definicyjne. W badaniach następuje proces jego deformalizacji i w konsekwencji dejurydyzacji, a od tego już tylko krok do rozumienia samorządu terytorialnego jako każdej formy udziału społeczeństwa lokalnego w życiu publicznym, a zatem samorządu w znaczeniu politycznym.

\section{TRADYCYJNA KONSTRUKCJA PRAWNA SAMORZADU TERYTORIALNEGO W WARUNKACH WSPÓŁCZESNOŚCI}

Trend do szerokiego definiowania samorządu terytorialnego ma niewątpliwie swoje zalety. Jest wyrazem przemian, jakie zachodzą we współczesnych społeczeństwach i w ślad za tym przekształceń instytucji samorządu terytorialnego. Jeszcze do niedawna samorzą terytorialny, definiowany jako zrzeszenie lokalnego społeczeństwa wykonujące, obok administracji rządowej, część funkcji wykonawczych państwa, miał ściśle określone miejsce w systemie ustrojowym państwa. Był traktowany w kategoriach jednego z dwóch pionów administracji publicznej i poza ową administrację nie wychodził. Zmiany społeczno-polityczne spowodowały, że przed administracja publiczna, w tym zwłaszcza samorządem terytorialnym, pojawiły się nowe zadania, takie, które przestały mieścić się w kategorii typowych dla administracji publicznej. Od administracji tej zaczęto bowiem wymagać nie tylko zaspokajania zbiorowych potrzeb obywateli, ale szerszej działalności na rzecz dobra wspólnego. I owej działalności oczekiwano zwłaszcza od samorządu terytorialnego jako tego podmiotu, który posadowiony jest najbliżej obywatela.

To szeroko określone działanie na rzecz dobra wspólnego stało się znakiem charakterystycznym dla samorządu terytorialnego, zwłaszcza gminy. Nic tedy dziwnego, że w związku z tym zaczęła zmieniać się perspektywa oglądu naukowego instytucji samorządu. Przedmiotem zainteresowania badawczego stały się nowe zjawiska charakterystyczne dla samorządności terytorialnej ${ }^{6}$. Na plan drugi przesunęły się kwestie stricte jurydyczne, w powszechnym przekonaniu dość dobrze zbadane.

W konsekwencji współcześnie zarówno nauka, jak i praktyka zdają się nie doceniać znaczenia jurydyzacji samorządu terytorialnego, a to ma konsekwencje w postaci rozmywania istoty tej instytucji. Na samorząd terytorialny coraz częściej patrzy się z perspektywy jego funkcji społecznych, na plan drugi przesuwając jego istotę prawną (wyodrębnioną w strukturze państwa korporację wykonującą funkcje administracji publicznej), i o ile nie ma to większego znaczenia w sytuacji niekwestionowania pozycji samorządu w państwie, o tyle

raz w recepcji idei zintegrowanego zarządzania publicznego. Jednak u nas zdecydowanie odrzuca się owe „państwowo-komunalne związki panowania”, kojarzące się z systemem ,jednolitej władzy państwowej w terenie", charakterystycznym dla czasów PRL, wykluczającym samorządność terytorialna w znaczeniu prawnym (Niewiadomski 2011: 223).

${ }^{6}$ Zob. np. Lipowicz (2019). 
tam, gdzie mechanizmy demokratyczne ulegają osłabieniu, odwoływanie się do samorządu terytorialnego jako instytucji prawnej ma znaczenie. Utrudnia bowiem sprowadzanie samorządu do roli jednej z form udziału społeczeństwa lokalnego w życiu publicznym, sui generis organizacji społecznej, z pominięciem głównego przymiotu właściwego samorządowi terytorialnemu (wykonywanie administracji publicznej przez upodmiotowione społeczności lokalne), i stoi na przeszkodzie próbom jego marginalizacji. Tworzy istotną gwarancję bytu prawnego samorządu, utrudniając sprowadzanie jego roli do zjawiska społeczno-politycznego, a nie instytucji prawnej.

Pokusa traktowania samorządu w kategoriach zjawiska społeczno-politycznego, a nie instytucji prawnej, pojawia się w szczególności w państwach rządzonych przez partie i ruchy populistyczne, dla których samorząd terytorialny - jak się zdaje - nie jest instytucją nadmiernie ważną. Nie jest taka, ponieważ często staje na przeszkodzie realizacji forsowanego nowego porządku ustrojowego, z reguły opartego na recentralizacji i osłabianiu mechanizmów demokratycznych ${ }^{7}$. Jako podstawowa instytucja społeczeństwa obywatelskiego jest zagrożeniem dla realizacji owego porządku forsowanego przez władzę, która choć demokratycznie wybrana, nie znosi sprzeciwu czy odmienności poglądów. Co więcej, samorząd staje się niekiedy wrogiem, z którym trzeba toczyć walkę. Stąd zapewne pomysły na recentralizację państwa i tym samym próby ograniczeń zadań i kompetencji samorządu. W sukurs tym działaniom zdają się przychodzić doktrynalne koncepcje samorządu terytorialnego jako instytucji społeczno-politycznej. Jeżeli bowiem samorząd terytorialny jest rozumiany szeroko jako każdy przejaw udziału społecznego w życiu publicznym, to punkt ciężkości reform samorządowych realizowanych w państwach rządzonych przez partie i ruchy populistyczne przenosi się na zapewnienie owego udziału w życiu publicznym, a nie utrzymanie istotnej części zadań publicznych we właściwości samorządu, czyli tego, co przesądza o samorządności terytorialnej w znaczeniu prawnym.

Znaczenia samorządu terytorialnego jako instytucji prawnej, a nie tylko zjawiska społeczno-politycznego, nie sposób zatem przecenić. Samorząd $\mathrm{w}$ znaczeniu prawnym jest fundamentem państwa demokratycznego. Bez samorządu terytorialnego w znaczeniu prawnym konstrukcja tego państwa staje się niestabilna i tworzy niebezpieczeństwo marszu w stronę autorytaryzmu. Jeżeli tak, to nie sposób mówić o samorządzie terytorialnym bez jego kontekstu jurydycznego. Dopiero samorząd terytorialny w znaczeniu prawnym zapewnia należne mu miejsce we współczesnym państwie. To zaś, że samorząd terytorialny jest współcześnie postrzegany nie tylko jako instytucja prawna, ale także jako podstawowa forma aktywności społecznej i najważniejszy filar społeczeństwa obywatelskiego, wcale nie oznacza, że traci na znaczeniu aspekt ustrojowoprawny, z natury rzeczy odwołujaccy się do formalizacji zjawiska. Owa formalizacja instytucji samorządu jest w dalszym ciagu niezbędna. Stanowi bowiem gwarancję pełnienia przez samorząd historycznie kształto-

7 Szerzej na ten temat Gomułowicz (2018): 67 n., oraz nr 7-8/2020 Przeglądu Prawa Publicznego zatytułowany: Prawo i populizm. 
wanej funkcji, tj. decentralizacji państwa, jego zadań i kompetencji. Bez formalizacji prawnej samorządu idea decentralizacji państwa jest zagrożona. Precyzyjne instytucjonalno-ustrojowe uregulowanie samorząu jest konieczne. Inaczej powstaje niebezpieczeństwo odejścia od istoty tej instytucji i jej przekształceń idących w kierunku instytucji wyłącznie politycznej, podatnej na doraźne wpływy polityczne. Jurydyzacja samorządu terytorialnego i akcentowanie jego instytucjonalno-prawnych rozwiazzań służy zatem ochronie jego samodzielności i możliwości dochodzenia należnych mu praw. W konsekwencji służy także interesom państwa, tworząc instytucjonalne gwarancje efektywnej realizacji zadań publicznych w warunkach współczesności.

\section{MIEJSCE SAMORZĄDU TERYTORIALNEGO WE WSPÓŁCZESNYM PAŃSTWIE ORAZ KSZTALT PRAWNY NADZORU JAKO PUNKT WYJŚCIA DOSTOSOWYWANIA KONSTRUKCJI PRAWNEJ SAMORZĄDU DO WYMOGÓW WSPÓŁCZESNOŚCI}

Skoro istota konstrukcji prawnej samorządu terytorialnego jest powołanie lokalnego społeczeństwa do samodzielnego wykonywania części zadań państwa, wykonywania administracji państwowej (publicznej), to poza sporem pozostaja jego związki z państwem ${ }^{8}$. Państwo może wywierać wpływ na działalność samorządu, tyle i aż tyle, że wpływ ten musi być określony przez prawo. W konsekwencji zdawać by się mogło, że to, co istotne dla bytu prawnego samorządu, nie budzi dzisiaj wątpliwości. Tak jednak nie jest. Aczkolwiek zerwano z poglądem, że samorząd jest strukturą przeciwstawną państwu, to pozostały wątpliwości co do miejsca samorządu w systemie ustrojowym państwa. Odnosząc się do tych poglądów, trzeba zauważyć, że nie ma żadnych racjonalnych względów, aby nie opowiedzieć się za poglądem, że samorząd terytorialny $\mathrm{w}$ sensie prawnym jest instytucją usytuowana $\mathrm{w}$ szeroko rozumianej strukturze państwa jako część jego władzy wykonawczej. Gdyby miało być inaczej, to tym samym należałoby uznać jego niezależność od państwa, uznać, iż jest podmiotem autonomicznym, równorzędnym wobec państwa, z konkurencyjnymi wobec niego zadaniami i uprawnieniami, a tego zdaje się

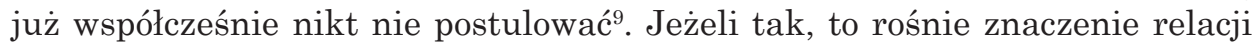
nadzorczych pomiędzy samorządem i organami nadzoru.

Nadzór jest centralną kategorią dla bytu prawnego samorządu terytorialnego i wbrew potocznym opiniom nie jest zagrożeniem, a gwarancją tego bytu, oczywiście przy założeniu właściwego ukształtowania jego istoty i zakresu. Instytucja nadzoru jest trwale związana z pojęciem decentralizacji. Podmiot, na rzecz którego zdecentralizowane zostały zadania i kompetencje, wykonuje

\footnotetext{
8 Podobnie Błaś (2002): 21; Wiktorowska (2002): 245.

9 Niewiadomski (2011): 218-219.
} 
je na podstawie prawa i w jego granicach, a legalność działania podlega ocenie organów nadzoru, którymi w przypadku jednostek samorządu terytorialnego są z reguły organy administracji rządowej, choć znane sa systemy ustrojowe, w których przedmiotowe uprawnienia pozostają we właściwości podmiotów samorządowych.

Nadzór zrodził się z potrzeby zapewnienia legalności działania jednostek tego samorządu, choć w jakiejś mierze również z potrzeby zintegrowana działalności podmiotów samorządowych wykonujących administrację państwowa $\mathrm{z}$ administracją rządowa. Stał się osią podziału struktur organizacyjnych na scentralizowane i zdecentralizowane ${ }^{10}$, rozwiązaniem po dziś dzień charakterystycznym dla struktur zdecentralizowanych, w których środki nadzoru wyznaczaja granice samodzielności podmiotu nadzorowanego, o ile oczywiście nie są nadmiernie rozbudowane. Jeżeli jest inaczej, nadzór staje się instrumentem państwowego sterowania jednostkami samorządu terytorialnego ${ }^{11}$, co w połączeniu z faktycznymi formami wpływu administracji rządowej na działalność samorządu (subwencje, pożyczki), w których to formach niektórzy autorzy dopatrują się „nadzoru nowoczesnego" ${ }^{12}$, powoduje, że rzeczywisty wpływ władz rządowych na samorząd odbiega od wzorca doktrynalnego.

Znakiem czasu jest, że nawet przy najlepiej skonstruowanych przepisach o nadzorze rzeczywisty zakres samodzielności samorządu jest uzależniony od różnego rodzaju pośrednich form wpływu władz nadzorczych na działalność samorządu. Decydując np. o przyznaniu środków finansowych, organy nadzoru moga decydować o rozwoju w skali lokalnej ${ }^{13}$. I mimo że owych pośrednich form wpływu władz rządowych na działalność samorządu nie można uznać za formalne akty nadzoru ${ }^{14}$, to nie sposób nie zauważyć, że nadzór prawny nie określa całokształtu stosunków: administracja rządowa - samorząd terytorialny, stając się jednym z elementów państwowego sterowania lokalnymi jednostkami ${ }^{15}$, gdzie „sprawdzanie poprawności aktu ustępuje miejsca kierowaniu określonym procesem" ${ }^{\prime 16}$. Taki stan rzeczy wywołuje oczywiście niezadowolenie władz lokalnych ${ }^{17}$.

${ }^{10}$ Zob. m.in. Wiener (1984): 157; a w rodzimej literaturze przedmiotu Starościak (1960): $13-41$.

${ }^{11}$ Podobnie Wiener (1984): 159.

${ }^{12}$ Moreau (1972): 26.

${ }^{13}$ Wiener (1984): 171.

${ }^{14}$ Szerzej Filipowicz (1984) oraz cytowana tam literatura.

${ }^{15}$ Knemeyer (1981): 265 n.; Siedentopf (1983): 149.

${ }^{16}$ Wiener (1984): 159. Warto podkreślić, że pogląd ten nie jest w literaturze francuskiej odosobniony. Zob. np. Pontier (1975): 371 i cytowana tam literatura.

${ }^{17}$ Już w literaturze międzywojennej nadzór rządowy nad samorządem był oceniany jako krępujący, a praktyka jego wykonywania była przedmiotem krytyki. Podnoszono, że „wartość samorządu terytorialnego w życiu państwowym, racja jego istnienia, rola, jaką ma spełniać, wymaga rzeczywistej swobody w ocenie i realizacji ciążacych na nim zadań państwowych, inaczej mówiąc w tworzeniu i konkretyzacji woli państwa w zakresie spraw lokalnych" (Przeorski 1938). Nie może być jednak czysto teoretyczna, o ile ma służyć zabezpieczenie samodzielności samorządu. Brak pełnej samodzielności samorządu jest przedmiotem krytyki w innych państwach, w szczsególności we Francji, i pochodzi głównie sprzed okresu reform administracyjnych z lat 1982-1983, ale po ich przeprowadzeniu nie ustaje (zob. m.in. Maciołek 1987: 29; Pierot 1985: 171 n.). Niezadowolenie, 
Jeżeli tak, to konieczne staje się spojrzenie na całokształt stosunków władze nadzorcze - samorząd terytorialny, tak aby ustalić rzeczywistą rolę nadzoru we współczesnych stosunkach administracji rządowej i samorządowej. Współcześnie bowiem nadzór rzeczywiście występuje tam, gdzie się go nie oczekuje, jest on rzadko tam, gdzie myśli się go szukać18.

Zdawać się może, że szansą na powrót do normalnosci w tej mierze jest sądowa kontrola legalności rozstrzygnięć nadzorczych, że sąd stanie w obronie samodzielności samorzadu, dając odpór działaniom organów nadzoru, niemieszczących się w katalogu formalnych środków nadzoru. Tak jednak nie jest, głównie za sprawą kryterium sądowej kontroli rozstrzygnięć nadzorczych. I choć legalność w zasadzie jest jedynym kryterium owej kontroli, co zdaje się korzystne dla jednostek samorządu terytorialnego, to występuje wyraźna rozbieżność pomiędzy prawem a praktyką. W praktyce, ale także i w literaturze przedmiotu, zwłaszcza obcej, podkreśla się, że zakres właściwości tych sądów uległ poszerzeniu w związku z ochroną praw podmiotowych jednostki, zyskująca prymat $\mathrm{w}$ orzecznictwie. To zaś generuje wzrost uznaniowości sądów w orzekaniu o prawie do samorządu i prowadzi pośrednio do kwestionowania demokratycznego aktu woli wyborców, i negatywnie wpływa na wolę czynnego uczestnictwa obywateli we wspólnotach samorządowych ${ }^{19}$. W orzecznictwie sądowym coraz częściej rozstrzyga się o legalności ingerencji nadzorczych na podstawie pojęć niedookreślonych, które z natury rzeczy wiażą się z koniecznością stosowania w pewnej mierze kryteriów celowościowych: np. sąd administracyjny orzeka o tym, czy rada gminy, uchwalając miejscowy plan zagospodarowania przestrzennego, pozostawała w granicach władztwa planistycznego, czy też go nadużyła. I aczkolwiek formalnie rzecz biorąc, sąd pozostaje przy kryterium legalności, badając, czy stosowna norma materialnoprawna przyznajacca gminie owe władztwo planistyczne nie została naruszona, to w istocie dokonuje ocen celowościowych.

\section{ZADANIA SAMORZĄDU TERYTORIALNEGO I PRAWNE ŚRODKI ICH REALIZACJI Z PERSPEKTYWY WSPÓŁCZESNOŚCI}

Jeszcze na początku XX w. zakres zadań samorządu terytorialnego był ograniczony. Sprowadzał się w zasadzie do zapewnienia bezpieczeństwa publicznego społecznościom lokalnym, opieki nad ubogimi, szkolnictwa podstawowego i elementarnej infrastruktury technicznej. Tak wasko ukształtowany zakres zadań samorządu wynikał z ówczesnych koncepcji dotyczacych miejsca i roli samorządu terytorialnego w państwie. W tym stanie rzeczy nie było większego problemu z materialnymi i prawnymi środkami realizacji zadań.

\footnotetext{
o którym mowa, występuje w innych krajach, nawet w Szwajcarii, gdzie zakres samodzielności samorządu jest wyjątkowo duży (zob. Meylan, Gottraux, Dahinden 1972: 261 n.).

${ }_{18}$ Melleray (1978): 402.

${ }^{19}$ Miemiec (2007): 170 i przywoływana tam literatura.
} 
Problem ten pojawił się wówczas, gdy nastapiło odejście od koncepcji samorządu o ściśle określonym, wąskim zakresie zadań. Wzrost zapotrzebowania na rozwój służb i instytucji publicznych, których administracja rządowa nie była w stanie organizować, sektor prywatny zaś nie był nimi zainteresowany z powodu niskiej opłacalności ${ }^{20}$, spowodował, że ukształtowały się warunki do rozszerzenia zakresu działania samorządu terytorialnego. Tendencje te uległy wzmocnieniu po II wojnie światowej. W rezultacie na przestrzeni ostatnich kilkudziesięciu lat zakres zadań samorządu terytorialnego rozszerzył się niepomiernie, a państwo, wychodząc z założenia ograniczonej pojemności kompetencyjnej administracji rządowej, przekazywało samorządowi szereg kolejnych zadań. Samorząd przeją w zasadzie wszystkie zadania, które bezpośrednio, a nawet pośrednio, kształtuja sytuację obywatela, przy czym nastapiło wyraźne przesunięcie akcentu z zadań o charakterze policyjno-porządkowym na zadania polegające na rozbudowie i utrzymaniu infrastruktury technicznej i społecznej, ale także oddziaływaniu na rozwój lokalny.

Tak dalece idące zmiany w zakresie zadań samorządu terytorialnego rodzą pytanie o adekwatność środków prawnych i materialnych koniecznych do realizacji owego rozbudowanego katalogu zadań. Rozpoczynam od środków prawnych. Środki te, ukształtowane w czasach, gdy zakres zadań samorządu terytorialnego był wąsko określony, zdają się nie przystawać do współczesnych potrzeb. O ile jeszcze środki o charakterze rozstrzygnięć indywidualnych sa w stanie podołać realizacji owych nowych zadan ${ }^{21}$, o tyle rozstrzygnięcia o charakterze generalnym, sprowadzające się wyłącznie do aktów prawa miejscowego to zdecydowanie za mało, aby uznać, że stanowią skuteczne instrumentarium prawne realizacji współczesnych zadań, pośród których pojawiają się takie, które wymagają stosowania aktów pośrednich pomiędzy aktami prawa powszechnie obowiązującego a aktami indywidualnymi i takie pojawiły się w szeregu państwach. Tymczasem polski samorząd nie ma do dzisiaj możliwości użycia środków prawnych o charakterze generalnym innych niż akty prawa miejscowego, mimo że przed organami jednostek samorządu terytorialnego stają zadania wymagające środków o charakterze generalnych aktów stosowania prawa, wywołujących skutki prawne na zewnątrz administracji, takie jak akty indywidualne, ale kierowane do bliżej nieokreślonej liczby adresatów. Katalog prawnych form działania niewątpliwie wymaga normatywnego uzupełnienia o generalne akty stosowania prawa ${ }^{22}$.

Z kolei w sferze stanowienia prawa powszechnie obowiązującego (aktów prawa miejscowego) konieczne jest wzmocnienie samodzielności prawotwórczej samorządu terytorialnego. I nie idzie o zapewnienie samorządowi możliwości stanowienia prawa miejscowego w sposób autonomiczny bez upoważnienia ustawowego, ale o poszerzenie możliwości stanowienia tego prawa

${ }^{20}$ Por. Ruśkowski (1984): 90.

${ }^{21}$ Szerzej na ten temat: Ziemski (2005).

${ }^{22}$ Czy też - jak je nazywają Ewa i Marek Szewczykowie - o generalne akty administracyjne (Szewczyk, Szewczyk 2014) lub przepisy administracyjne, jak określił je Michał Kulesza (Kulesza 2000: 9). 
zgodnie z normą ustawową ogólnie upoważniająca, a nie przede wszystkim na podstawie upoważnienia konkretnego. Zatem to, co dzisiaj jest wyjątkiem: możliwość stanowienia prawa miejscowego na podstawie ogólnej normy upoważniającej, określonej w przepisach ustaw samorządowych ${ }^{23}$, powinno ulec znacznemu poszerzeniu.

Wreszcie rozbudowy wymaga instrumentarium prawne realizacji coraz szerszej gamy zadań samorządu spoza wasko rozumianej administracji publicznej. Co prawda w odniesieniu do części tych zadań niewymagających aktów władczych samorząd dysponuje możliwościami konsultacji, dajacymi mu przymiot administracji konsultacyjnej, ale daleko jeszcze polskiemu samorządowi do choćby francuskiej administracji negocjacyjnej, charakterystycznej dla czasów współczesnych.

O ile postulowane uzupełnienie katalogu środków prawnych niezbędnych dla realizacji zadań przez samorząd terytorialny jest stosunkowo proste, ponieważ wymaga stosownej interwencji ustawodawcy, o tyle rozwiązanie problemu materialnego zabezpieczenia realizacji zadań samorządu jest o wiele trudniejsze. Trudna sytuacja finansowa samorzadu terytorialnego to sytuacja powszechna w świecie. Istotnie dotyka samorząd w Polsce. Obarczenie samorządu realizacją szerokiej sfery zadań, i to tak kosztownych jak np. oświata, powoduje, że nie zawsze całość wpływów łącznie z subwencjami wystarcza na pokrycie wydatków. Zwiększające się potrzeby finansowe oraz często ujemny bilans budżetów lokalnych powoduja, że rośnie stan zadłużenia samorządu. Wiąże się to z koniecznością finansowania wydatków związanych z potrzeba dostosowywania poziomu życia mieszkańców do wysokich wymagań współczesności, a także kosztami nowoczesnego procesu administrowania. W rezultacie samorząd znalazł się w trudnym położeniu materialnym. Sytuacja staje się niepokojąca, i to nie tylko w aspekcie gospodarczym, lecz także w aspekcie zagrożenia samodzielności samorządu.

\section{INNE UWARUNKOWANIA FUNKCJONOWANIA WSPÓLNOT LOKALNYCH I ICH WPLYW NA PRZEKSZTALCENIA INSTYTUCJI PRAWNEJ SAMORZĄDU TERYTORIALNEGO}

Niewątpliwie jednym z wyzwań, przed jakim staje współczesny samorząd terytorialny, jest zjawisko umiędzynarodowienia administracji publicznej, w tym samorządu terytorialnego. Kształtowanie się europejskiej administracji publicznej, ale także wzrost roli i znaczenia współpracy w szerszych strukturach międzynarodowych istotnie zmieniają standardy organizacji i funkcjonowania samorządu. Kształtowanie się europejskiej administracji publicznej przejmującej część funkcji administracyjnych państw członkowskich UE i wymuszającej wspólną realizację niektórych zadań wespół z „anektowaniem” czę-

${ }^{23}$ Zob. art. 40 ust. 1 u.s.g., art. 40 ust. 1 u.s.p. i art. 40 ust. 1 u.z.w. 
ści zadań krajowych administracji publicznych przez organizacje międzynarodowe wpływa na zakres działania krajowych podmiotów administracyjnych, $\mathrm{w}$ tym jednostek samorządu terytorialnego. Następuje rozpraszanie funkcji administracji publicznej poszczególnych krajów na instytucje krajowe i międzynarodowe. Zmianie ulega sposób i standard wykonywania zadań. Niemała rolę odgrywają w tym międzynarodowe sądy i trybunały, a w szczególności Trybunał Sprawiedliwości Unii Europejskiej.

Kolejnym wyzwaniem dla samorządu terytorialnego staje się społeczeństwo informacyjne. Dygitalizacja administracji publicznej, zwłaszcza na poziomie samorządu terytorialnego bezpośrednio kontaktującego się z obywatelem, rodzi szereg niespotykanych dotąd problemów. Ułatwiając realizację zadań, generuje nowe problemy, $\mathrm{z}$ ochrona danych osobowych na czele.

Nie bez wpływu na ustrój współczesnego samorządu terytorialnego pozostaje utrzymujaca się tendencja do ekonomizacji usług publicznych, powodując, że w innym świetle jawi się koncepcja finansowania usług publicznych z propozycją przenoszenia części kosztów na użytkowników. W ślad za tym jesteśmy blisko rewizji istoty i zakresu odpowiedzialności publicznej samorządu za standard i powszechną dostępność tych usług.

Niezależnie od wyżej wymienionych nowych zjawisk wpływajacych na potrzebę zmian $\mathrm{w}$ samorządzie terytorialnym, odżywaja problemy, które pojawiły się wcześniej, a dotąd nie zostały rozwiązane, pośród nich zaś kwestia materialnego zabezpieczenia realizacji jego zadań. Rozbudowany katalog tych zadań wespół z dyktowanymi wymogami współczesności coraz wyższymi standardami ich realizacji prowadzi do pogarszania się sytuacji finansowej poszczególnych jednostek samorządu terytorialnego. Ta zaś rodzi pilną już konieczność zbudowania mechanizmów prawnych, które wychodząc z tego stanu rzeczy, tworzyłyby źródła nowych dochodów, a przynajmniej kształtowały zasady funkcjonowania samorządu w sytuacji niedoboru środków finansowych. Zadawnionym problemem jest potrzeba przekształceń wewnętrznych procesów decyzyjnych. Idea demokracji bezpośredniej, leżąca u podstaw tradycyjnej konstrukcji samorządu, już od dawna przestała funkcjonować i ostała się w formie szczątkowej. Punkt ciężkości przesunął się z bezpośredniego udziału lokalnych społeczeństw w wykonywaniu administracji państwowej na formy udziału pośredniego. Rozrost i profesjonalizacja zadań publicznych powoduja, że już nie tylko wspólnota lokalna, ale nawet jej przedstawicielstwo nie jest w stanie podejmować i rozwiązywać wszystkich problemów. Z konieczności musi się ograniczyć do inspiracji i kontroli. Podstawową rolę pełnią organy wykonawcze i zespoły eksperckie. W tej sytuacji, niezależnie od oceny tego zjawiska, konieczne jest poszukiwanie innych niż dotychczas form wpływu lokalnych społeczności na działalność organów samorządu terytorialnego. Rozbudowy wymaga system konsultacji społecznych oraz instytucja mediacji.

W tym miejscu trzeba podnieść, że wszystkie zmiany wymienione w tym punkcie mają inny charakter niż wcześniej analizowane. Sa zmianami nienaruszającymi istoty prawnej samorządu terytorialnego i jako takie mogą być przeprowadzone bez szkody dla kształtu prawnego tej instytucji. 


\section{KONKLUZJE}

Samorząd terytorialny jako konstrukcja prawna jest fenomenem, którego znaczenia w warunkach państwa demokratycznego nie sposób przecenić. To zaś, że konstrukcja wymaga przekształceń w dostosowaniu do warunków współczesności, w żadnym razie nie deprecjonuje jej znaczenia. Nie ulega wątpliwości, że samorząd terytorialny jest współcześnie czymś więcej niż korporacją (wspólnotą lokalnego społeczeństwa), na rzecz której decentralizowane sa zadania publiczne, że stał się podstawową instytucją społeczeństwa obywatelskiego, formą aktywności społecznej, wreszcie organizacją działającą na rzecz dobra wspólnego, ale to nie powód do odwracania uwagi od samorządu jako owej korporacji mieszkańców sprawującej administrację publiczną, a zatem samorządu w znaczeniu prawnym.

Trzeba expressis verbis stwierdzić, że również w warunkach współczesności instytucji samorządu terytorialnego w znaczeniu prawnym nie da się zastapić żadną inną konstrukcją. Samorząd terytorialny, w kształcie zrodzonym w przeszłości, jest integralną częścią współczesnego państwa i społeczeństwa. Bez samorząu terytorialnego w znaczeniu prawnym nie sposób wyobrazić sobie państwa demokratycznego. Wspólnoty lokalne, sprawujące administrację publiczna, upodmiotowiane na przestrzeni lat, na trwałe wrosły w system ustrojowy państwa. Sama obecność konstrukcji prawnej samorządu terytorialnego w warunkach współczesności jest zatem bezsporna. Sporne mogą być jedynie kwestie powstające w związku z potrzebą dostosowania do wymogów współczesności. Szeroko rozbudowana planistyczna i reglamentacyjna funkcja państwa zmuszająca do decentralizacji zadań, wymogi nowoczesnego procesu administrowania, wreszcie szeroka działalność na rzecz dobra wspólnego nie moga pozostać bez wpływu na kształt dziewiętnastowiecznej konstrukcji samorządu. Jeżeli w dalszym ciagu ma demokratycznie i efektywnie funkcjonować, musi ulec przekształceniom, ale przekształcając się, samorząd nie może zatracić tego, co go statuuje jako instytucję prawną.

Jeżeli tak, to konieczna jest obrona klasycznej instytucji prawnej samorządu terytorialnego, tak aby w pogoni za efektownymi rozważaniami, o słusznej skądinąd potrzebie dostosowywania samorządu do wymogów współczesności, nie zatracić tego, co w tej instytucji trwałe i niezmienne. Chodzi o jądro, które umożliwia trwanie przedmiotowej instytucji. Tym jądrem samorząu jest wykonywanie administracji publicznej przez upodmiotowione lokalne społeczności.

Trzeba skonstatować, że dla instytucji prawnej samorządu terytorialnego nie ma alternatywy. W szczególności nie może nią być idea rozproszonych podmiotów wykonujących administracje publiczną w terenie. Nie może, ponieważ charakter przeważającej części zadań przekazanych wspólnotom lokalnym z natury rzeczy wymaga jednolitości wykonawstwa, choć w skali lokalnej, co oczywiście nie wyłącza możliwości wspierania działań samorządu przez inne podmioty. Tym bardziej alternatywą dla samorządu terytorialnego w owym prawnym znaczeniu nie może być pozostawienie spraw lokalnych w gestii terenowych organów administracji rządowej, i to co najmniej z dwóch względów. 
Po pierwsze, oznaczałoby to nieefektywną centralizację systemu wykonywania administracji publicznej. Po drugie zaś, powodowałoby utratę podmiotowości prawnej przez społeczności lokalne i autorytarną władzę centralna. Nieefektywność i autorytaryzm takiego rozwiązania zostały dowiedzione teoretycznie, a także w czasach PRL empirycznie.

Jeżeli tak, to przed nauka prawa staje zadanie określenia, co w instytucji prawnej samorządu jest stałe i niezmienne, a co powinno ulegać zmianom w ślad za wymogami współczesności. Wyżej wspomniane zadanie, choć z natury majace charakter doktrynalny, nie jest też pozbawione znaczenia dla praktyki.

Podejmując próbę określenia tego, co w instytucji prawnej samorządu terytorialnego jest niezmienne i przesądza o bycie samorządu, koncentruję się na celu i zakresie podmiotowym instytucji. Celem powołania do życia samorządu terytorialnego było włączenie lokalnych społeczności do realizacji części zadań administracji państwowej (publicznej). Cel ten po dziś dzień pozostaje aktualny, choć w miarę upływu czasu pojawiły się kolejne ważne funkcje samorządu, łączące się z realizacją idei społeczeństwa obywatelskiego i pracy na rzecz dobra wspólnego. Nie deprecjonując owych późniejszych funkcji, trzeba podkreślić, że ich pojawienie się w żadnym razie nie niweczy pierwotnego celu instytucji samorządu terytorialnego. To właśnie m.in. dlatego, że samorząd wykonuje administrację publiczna, może być traktowany jako podstawowa instytucja społeczeństwa obywatelskiego, jako że ową administrację wykonuja społeczności lokalne, na rzecz których zdecentralizowano część zadań państwa (administracji publicznej) do samodzielnego stanowienia. To zaś oznacza, że samorząd terytorialny wiąże się z procesem upodmiotowienia społeczności lokalnych, charakterystycznym dla społeczeństwa obywatelskiego. Jeżeli tak, to owej decentralizacji administracji publicznej na rzecz lokalnych społeczności nie sposób nie uznać za cechę leżącą u podstaw instytucji prawnej samorządu, cechę w istocie kreującą samorządność terytorialną w znaczeniu prawnym. To zaś, że współcześnie funkcje samorządu terytorialnego wychodzą poza wykonywanie administracji publicznej, w żadnym razie nie upoważnia do traktowania go w kategoriach organizacji pozapaństwowej, sui generis organizacji społecznej, choćby najważniejszej. Nie upoważnia też do stawiania tezy, że samorząd terytorialny w warunkach współczesności ewoluuje w takim stopniu, że staje się podmiotem o cechach jakościowo różnych w stosunku do tych, które go ukształtowały. Nie znajdują racjonalnego uzasadnienia tezy o jego autonomii, a więc strukturze od państwa niezależnej, ani tezy o przekształceniu tradycyjnej konstrukcji prawnej samorządu w twór jakościowo odmienny. A już całkowicie niezrozumiale brzmi myśl o potrzebie budowy samorządu wolnego od formalizmu prawnego, odzwierciedlającego jego wyłącznie społeczny charakter bez kontekstu związku z państwem. Tego typu koncepcje samorządu, rozumianego jako tworu wyłącznie społecznego, pozostającego poza strukturą państwowa, to w istocie propozycje odejścia od samorządu terytorialnego w znaczeniu prawnym na rzecz samorządu w znaczeniu politycznym, rozumianego jako każda forma udziału społecznego w życiu publicznym, a im więcej tych form, tym lepiej (opiniowanie, konsultowanie itp.). Tyle że tak 
rozumiany samorząd tworzy na gruncie ustrojowym niebezpieczeństwo jego fasadowego traktowania, charakterystycznego m.in. dla ruchów populistycznych i radykalnych.

To wszystko prowadzi do wniosku, że na gruncie ustrojowym tradycyjna konstrukcja prawna samorządu terytorialnego jest niezastapiona, jest wartościa trudną do przecenienia, a ostoją tej konstrukcji jest związek instytucjonalny samorządu z państwem, wyrażony w formie zdecentralizowanej na rzecz społeczności lokalnych części władzy wykonawczej państwa (administracji publicznej). Ustaliwszy to, co w instytucji prawnej samorządu niezmienne, a zatem samą ideę powołania lokalnego społeczeństwa do wykonywania administracji publicznej w sposób samodzielny przy zapewnieniu odpowiednich materialnych i prawnych środków realizacji zadań, z ustawowo określonym, ograniczonym zakresem ingerencji nadzorczej, można przejść do poszukiwania tego, co w instytucji prawnej samorządu terytorialnego powinno się zmieniać. Nie ulega wątpliwości, że współcześnie samorząd terytorialny funkcjonuje w warunkach daleko odbiegających od tych, które go ukształtowały. Nie sposób też nie zauważyć, że samorząd podąża za zmieniajacym się otoczeniem. Jest przecież - tak jak cała administracja publiczna - zjawiskiem dynamicznym $^{24}$. Tylko czy tempo tych zmian jest wystarczające? Czy samorząd terytorialny w stopniu wystarczającym podąża za takimi wymogami współczesności, jak: globalizacja, informatyzacja i umiędzynarodowienie działalności samorządu czy nieuniknionym trendem do ekonomizacji działania oraz aktywności w działaniach na rzecz rozwoju społeczno-gospodarczego w skali lokalnej? Wydaje się, że nie, choć odpowiedź na tak postawione pytanie wymaga odrębnych pogłębionych badań.

Zygmunt Niewiadomski

Szkoła Główna Handlowa w Warszawie

https://orcid.org/0000-0001-7118-2719

zniewi@sgh.waw.pl

Błaś, A. (2002). Reaktywowanie samorządu terytorialnego w Rzeczypospolitej Polskiej w 1990 r., [w:] Studia nad samorządem terytorialnym. Kolonia Limited.

Box, C. (2007). Democracy and Public Administration. M.E. Sharpe, Inc.

Filipowicz, A. (1984). Pojęcie i funkcje nadzoru w administracji. Ossolineum.

Fox, C., Miller, H.T. (1995). Postmodern Public Administration. Toard Discourse, Sage, Thousand. Oaks.

Gomułowicz, A. (2018). Oblicze polskiej dyktatury. Nauka 3: 67-80

Guy, P.B. (1999). Administracja publiczna w systemie politycznym. Warszawa.

Knemeyer, F.L. (1981). Die Staatsaufsicht über die Gemeinden und Kreise, [w:] Handbuch der kommunalen Wissenschaft und Praxis. 2. Auflage. Band 1. Springer: 265-287.

Kulesza, M. (2000). Przepisy administracyjne w zamkniętym systemie źródeł prawa. Samorząd Terytorialny 10(9).

Lipowicz, I. (2019). Samorzą terytorialny XXI wieku. Warszawa.

Maciołek, M. (1987). Komisarz Republiki - kontynuator funkcji prefekta. Organizacja-MetodyTechnika 3: 29.

Melleray, G. (1978). La tutelle de l'état sur le communes. Broché.

24 Szerzej Niewiadomski (2011): 
Meylan, J., Gottraux, M., Dahinden, P. (1972). Schweizer Gemeinde und Gemeindeautonomie. Lausanne.

Miemiec, M. (2007). Gmina w systemie administracji publicznej Republiki Federalnej Niemiec. Kolonia Limited.

Moreau, J. (1972). Administration regionale, locale et municypale. Dalloz.

Niewiadomski, Z. (2011). Samorząd terytorialny, [w:] System prawa administracyjnego. Tom 6. Warszawa.

Piekara, A. (1990). Wartości i funkcje samorządu terytorialnego. Państwo i Prawo 45(8): 3-13.

Pierot, R. (1985). Samodzielność finansowa związków lokalnych i niedawne reformy decentralizacyjne we Francji. Problemy Rad Narodowych 62.

Pontier, J.M. (1975). La repartition des competences entre l'Etat et les collectivites locales. Paris.

Przeorski, T. (1938). Samorząd Miejski 13.

Ruśkowski, E. (1984). Problemy decentralizacji finansowej we Francji. Problemy Rad Narodowych 59.

Siedentopf, H. (1983). Kontrola administracji przez izby obrachunkowe, [w:] Administracja Republiki Federalnej Niemiec. Ossolineum.

Starościak, J. (1960). Decentralizacja administracji. Warszawa.

Staryszak, J. (1931). Prawo nadzoru nad administracją samorządową w Polsce. Warszawa.

Szewczyk, E., Szewczyk, M. (2014). Generalny akt administracyjny. Między indywidualnym aktem administracyjnym, a aktem normatywnym. Warszawa.

Wiener, C. (1984). Władza centralna i władza lokalna - Mity i rzeczywistość. Kontrola czy ingerencja, [w:] J. Łętowski (red.). Administracja Republiki Francuskiej, Ossolineum.

Wiktorowska, A. (2002). Prawne determinanty samodzielności gminy. Warszawa.

Ziemski, K. (2005). Indywidualny akt administracyjny jako prawna forma działania administracji. Poznań.

\section{ON THE IMPORTANCE OF THE TRADITIONAL LEGAL STRUCTURE OF LOCAL SELF-GOVERNMENT IN CONTEMPORARY TIMES}

\section{Sum mary}

Until recently, the institution of local self-government has been studied in the legal sciences as a legal structure (a separate local community autonomously performing public administration functions). The fact that local government has embraced other functions applicable in contemporary times has resulted in a shift in research focus. New functions of self-government, going beyond public administration (acting for the common good and civil society), have come to the fore. These functions sometimes tend to become the main element in the definition of local selfgovernment, weakening the existing main function of self-government in the legal sense (the exercise of public administration). This, in turn, creates the danger of self-government being treated as a purely political phenomenon, thus seeking to weaken the position of local self-government, in particular in authoritarian states ruled by populist parties.

Keywords: public administration; local self-government; local self-government transformation; local self-government in the legal sense; local self-government in the political sense; social functions of local self-government; tasks of local self-government; supervision over local self-government 
